\title{
Professional culture formation of future specialists in physical therapy and ergotherapy at higher education institutions
}

\author{
OLGA ANDREIEVA ${ }^{1}$, NATALIIA HRYTSAI ${ }^{2}$, ROSTYSLAV SHYKULA ${ }^{3}$, LYUBOV KRAVCHENKO $^{4}$ \\ ${ }^{1}$ Department of Medical and Psychological Disciplines, National University of Water and Environmental \\ Engineering, UKRAINE \\ ${ }^{2}$ Department of Natural Sciences with Teaching Methods, Rivne State University of Humanities, UKRAINE \\ ${ }^{3}$ Department of Geography and Tourism, Academician Stepan Demianchuk International University of \\ Economics and Humanities, UKRAINE \\ ${ }^{4}$ Department of Culturology and Methods of Teaching of the Culturological Disciplines, Poltava \\ V. G. Korolenko National Pedagogical University, UKRAINE
}

Published online: October 30, 2021

(Accepted for publication October 15, 2021)

DOI:10.7752/jpes.2021.s5386

\begin{abstract}
:
The professions of physical therapist and ergotherapist are becoming increasingly important nowadays. The article is devoted to the formation of professional culture of future physical therapists and ergotherapists in the process of professional training in higher education institutions. It is established that professional culture is an integral quality of personality, which projects its general culture into the sphere of profession and covers a high level of professionalism and internal qualities of a specialist. It is a component of the general culture of the individual, based on the professional knowledge, skills, values, motives and norms of behavior that contribute to the effective performance of professional activities. Empirical (questionnaires, interviews, surveys, observations, testing to determine the level of professional culture of future bachelors in physical therapy and ergotherapy, pedagogical experiment) and theoretical (analysis, synthesis, comparison, generalization) methods of research were used in this study. The components of professional culture of future physical therapists and ergotherapists (motivational, cognitive, activity orientated and reflexive), relevant criteria (person-motivational, informationcognitive, communicative-activity and reflexive-empathetic), indicators and levels of measurement of physical culture formation of future physical therapists and ergotherapists are determined. The pedagogical experiment involved the introduction of the author's system of professional culture formation of future physical therapistsand ergotherapists in the process of professional training in higher education institutions. The results of the experiment led to the conclusion that the implementation of contextual learning in professional disciplines, the formation of soft skills, the development of reflection and empathy of applicants contribute to improving the professional culture of future professionals in specialty 227 «Physical Therapy, Ergotherapy». In the experimental groups, the level of professional culture of future physical therapists and ergotherapists increased by each component. The professional culture formation of future physical therapists and ergotherapists is a mandatory component in their professional training in higher education institutions.
\end{abstract}

Key words: professional training, professional culture, physical therapy and ergotherapy, contextual education, components.

\section{Introduction}

Recent world events caused by the COVID-19 coronavirus pandemic have led to a rethinking of the values of modern humanity. Occupations, that are related to human health, have become the most needed and in demand today. Most people's attitudes towards health professionals have changed significantly, as the health and life of everyone depends directly on the professionalism of doctors.

At the same time, the war in Donbass has led to a huge demand for military medics and physical therapists (rehabilitation specialists), who are engaged in restoring the damaged parts of the human body. Taking this into account, the speciality 227 «Physical Therapy, Ergotherapy» (that was named «Physical Rehabilitation» by 2017) is becoming increasingly popular in higher education institutions of Ukraine (Resolution of the Cabinet of Ministers, 2017).

Thus, only in the city of Rivne, four establishments of higher education prepare future experts on this specialty: Rivne State University of Humanities, National University of Water and Environmental Engineering, Academician Stepan Demianchuk International University of Economics and Humanities, Rivne Medical Academy. A number of scientific researches are devoted to the problem of preparation of future specialists in physical therapy and ergotherapy (Korpi H. et al., 2017; Soltyk et al., 2017; Sushchenko, 2015; Hrytsai, 2020; Kopochynska, 2020e). In the doctoral thesis by Yu. Liannoi, the system of professional training of future masters in physical rehabilitation is substantiated, where the emphasis is taken into account in the content of training 2908 
higher education features of professional activity, development of experience in an interdisciplinary team during internships and research, means of shaping values of undergraduates to scientific and professional activities (Liannoi, 2017). O. Bespalova studied the preparation of bachelors in physical therapy and ergotherapy for the use of physical culture and health technologies (Bespalova 2019). O. Sushchenko examined the development of professional competence of masters - physical therapists and ergotherapists during their work practice (Sushchenko, 2019). O. Bazylchuk explored the readiness of future specialists in physical therapy and ergotherapy in their work of restoring the health of athletes, which includes personality qualities, motives, aspirations, stable attitudes to targeted actions to restore the ability of people involved in sports (Bazylchuk, 2018; Bazylchuk, 2019). The experience of training specialists in physical therapy, ergotherapy in European countries is analyzed in detail in the scientific researches by N. Bielikova (Bielikova, 2010a; Bielikova, 2010b), I. Mordvinova, A. Olkhovyk (Mordvinova, 2018) and others.

The task of higher education institutions is to train future specialists in physical therapy and ergotherapy, who will not only have professional knowledge and skills, but will have the appropriate level of professional culture, which will ensure the quality of their functional responsibilities.

The purpose of the article is to clarify the peculiarities of the formation of professional culture of future specialists in physical therapy and ergotherapy in order to improve their professional training in higher education institutions.

The standard of higher education of the first (bachelor's) level, an area of expertise «Health», speciality 227 «Physical Therapy, Ergotherapy» (Standard of higher education, 2018) lists the general and special competencies, among which we can distinguish the ability to act on the basis of ethical considerations, being socially responsible and conscious, to preserve and multiply moral, scientific, cultural values, etc. Such competencies contribute to the formation of the professional culture of future physical therapists and ergotherapists. In addition, the development of soft skills is of great importance, which includes the abilities to work in a team and people motivation, interpersonal skills, planning, time management and others.

Professional culture involves a combination of qualification requirements and personal values.

Theoretical analysis of the scientific literature gives grounds to assert that professional culture is an integral quality of personality, which projects its general culture into the sphere of profession and covers a high level of professionalism and internal qualities of a specialist. It is a component of the general culture of the individual, based on the professional knowledge, skills, values, motives and norms of behavior that contribute to the effective performance of professional activities (Diachenko-Bohun et al., 2019; Gusak, 2010; Nalyvayko, 2016; Yakuba, 1996).

The specifics of physical therapists and ergotherapists job includes the presence of certain professional and personal qualities. The professional culture is a certain core of specialist's personality in this sphere. In our opinion, professional culture is a set of norms and rules of behavior, values, characteristic of a certain professional activity.

Therefore, the professional culture of future specialists in physical therapy and ergotherapy will be an integrative characteristic of their preparation for future professional activities, which is based on highly developed personal qualities, knowledge and values, general and professional competencies that project the general culture of the profession, all these features contribute to quality performance of professional tasks. Professionally significant personality qualities, values of professional activity, norms, rules and ways of behavior are the main components of professional culture. A physical therapist and an ergotherapist, in addition to having a high level of professional competence, must be able to communicate with their patients, be tolerant, polite, sensitive, empathetic, they must also follow professional ethics.

\section{Materials and Methods}

A set of research methods are used in the formation of professional culture of future bachelors in physical therapy and ergotherapy during their professional training in order to achieve the desired objective: theoretical: analysis of scientific literature, educational programs, curricula and working programs of academic disciplines in the specialty 227 «Physical therapy, occupational therapy», synthesis, comparison, generalization; empirical: questionnaires, interviews, surveys, observations, testing to determine the level of professional culture of future bachelors in physical therapy and ergotherapy; pedagogical experiment is used for testing the effectiveness of the professional culture formation of future bachelors in physical therapy and ergotherapy; methods of mathematical statistics.

The process of the professional culture forming of future specialists in physical therapy and ergotherapy is an important condition for their professional training. Therefore, the content of higher education training for the speciality 227 «Physical Therapy, Ergotherapy» provided for disciplines that aimed at forming the professional culture of the future specialist.

In particular, at Rivne State University of Humanities, bachelors of physical therapy study philosophy, history of Ukrainian culture, pedagogy, general and clinical psychology, basics of sociology and law, which belong to the compulsory disciplines. In addition, applicants for higher education are offered the following elective subjects: correctional pedagogy, inclusive education, business ethics, social psychology, psychology of healthy living, psychology of additive behavior (Educational program, 2020). These disciplines, as well as 
training and work practices (general introductory practice in the profile of the future profession, clinical practice in diseases of the cardiovascular system, clinical practice in diseases of the respiratory system, clinical practice in musculoskeletal disorders, clinical practice in nervous system disorders) have a positive effect on the professional culture formation of future specialists in physical therapy and ergotherapy.

In addition, professional disciplines are important for the formation of professional culture. The Standard of Higher Education does not specify those teaching methods and technologies that are necessary for the full professional culture formation of the future specialist. The developers of the standard indicate only observation, survey, measurement, testing, verbal and nonverbal communication (Standard of higher education, 2018), but they are not teaching methods.

The professional culture of students was determined by four components: motivational, cognitive, activity orientated and reflexive. For objective determination of the formation level for each of the professional culture components, appropriate criteria (person-motivational, information-cognitive, communicative-activity and reflexive-empathic), indicators and levels (low, medium and high) of measuring of professional culture formation of future physical therapists and ergotherapists as well as diagnostic tools (techniques) for their measurement are selected.

The experiment involved 246 students of higher education institutions in the city of Rivne, who study in the specialty 227 «Physical Therapy, Ergotherapy». The pedagogical experiment consisted of two stages: ascertaining and forming.

The ascertaining stage of the research was carried out in order to determine the initial level of professional culture formation of future bachelors in physical therapy and ergotherapy in the process of their professional training. The experiment involved two groups of applicants for higher education: an experimental group (EG) and a control group (CG). Representatives of both groups had low indicators of professional culture on each criterion.

We took into account the professional motivation of applicants for higher education, their professional values and the ability to self-improvement in determining the person-motivational criterion. Testing, interviews, observations and surveys were used for this criterion testing.

In the course of establishing the level of professional culture of higher education applicants, according to the person-motivational criterion, a survey «Why did you choose this profession?» was conducted. Most applicants (62\%) made their choice consciously and they are confident in its correctness (this is due to the prospects of the profession of a physical therapist and an ergotherapist). Only $10 \%$ of responders went to study by accident « they were forced by their parents», $28 \%$ of responders went to study « by true calling in their life». The responders answered the question «Do they have an idea about their profession?» 45\% of applicants responded in an affirmative way, $38 \%$ of them have general ideas about it, $17 \%$ of responders do not have any idea about it.

A questionnaire «Motivation of professional activity» (a method of determining the motives of professional activity by K. Zamfir) (Batarshev et al., 2007; Psychological tests, 2002), a questionnaire «Motivation for achievement in professional activity» by A. Karelina were used during the experiment to diagnose the motivational component of the future physical therapists and ergotherapists professional culture (Psychological tests, 2002).

The information-cognitive criterion included checking the level of knowledge of students in professional disciplines that are related to the professional culture of future physical therapists and ergotherapists. Control works and performance of test tasks were used for this purpose.

The communicative-activity criterion made it possible to assess the skills of professional activity of future physical therapists and ergotherapists with the help of a self-assessment questionnaire of professional skills, as well as methods of identifying communicative and organizational tendencies (Batarshev et al., 2007).

The reflexive-empathic criterion is especially valuable, which allows determining the level of professional empathy of future professionals, the ability to analyze the results of their activities (Ziebart et al., 2019). The test according to this criterion was performed by using the method of diagnosing the level of empathy by V. Boyko (Boyko, 2002), as well as the questionnaire «Self-assessment of creative potential» on the basis of students' self-assessment of the formation of their professionally significant personal qualities was conducted (Batarshev et al., 2007).

A formative experiment was conducted in higher education institutions in the city of Rivne in order to increase the levels of professional culture formation of students for each of the components.

Within the experiment, we paid attention to the fact, that the training of higher education seekers should take into account the contextual approach, mainly through the acquisition of theoretical knowledge and the formation of practical skills in the context of the future profession. During the contextual training, the process of information transmission was not in priority, but the development of students' competencies aimed at performing professional functions, solving problems and tasks was prioritized (Verbitsky, 2004). In contrast to traditional learning, which simply conveys the content of certain scientific disciplines, in contextual learning the future professional activity is also the source of learning, which involves the study and mastery of basic professional tasks and functions. 
During the organization of professionally oriented training of future physical therapists and ergotherapists, specific content, forms, methods and teaching aids were selected that would bring higher education students closer to future professional activity and this would contribute to the formation of professional culture in future specialists.

The methods of realization of contextual training of future physical therapists and ergotherapists are determined by the use of technologies of problem-based, reflective, dialogue, project-based learning, etc.

It was effective to conduct various types of lectures (visualizations), use business games, solve cases, projects implementation that directly relate to future professional activities (Hrytsai, 2019).

Individual tasks were aimed at expressing the subjective position of higher education students in solving specific professional-oriented problems.

\section{Results}

Here are the results of a pedagogical experiment in higher education institutions in the city of Rivne.

After the implementation of the system of future physical therapists and ergotherapists professional training, which is focused on the formation of their professional culture, the introduction of contextual training of future professionals, there were changes in the levels of formation for each component of students' professional culture.

We present the results of measuring the level of professional culture formation of future physical therapists and ergotherapists of the control and experimental groups in the form of tables 1 and 2 . The reliability of the research results was proved using Pearson's criterion.

Table 1. The results of the forming experiment in the control and experimental groups

\begin{tabular}{|l|l|l|l|l|l|l|l|}
\hline $\begin{array}{l}\text { Component of } \\
\text { professional culture }\end{array}$ & Sec-tion & \multicolumn{2}{|l|}{ Low } & \multicolumn{2}{l|}{ Medium } & \multicolumn{2}{l|}{ High } \\
\hline \multirow{2}{*}{ Motivational } & I & $33,5 \%$ & $38,3 \%$ & $54,3 \%$ & $49,9 \%$ & $12,2 \%$ & $11,8 \%$ \\
\cline { 2 - 8 } & II & $29,4 \%$ & $22,1 \%$ & $56,7 \%$ & $56,4 \%$ & $13,9 \%$ & $21,5 \%$ \\
\hline \multirow{2}{*}{ Cognitive } & I & $40,5 \%$ & $39,1 \%$ & $49,8 \%$ & $55,2 \%$ & $9,7 \%$ & $5,7 \%$ \\
\cline { 2 - 9 } & II & $39,4 \%$ & $14,8 \%$ & $48,4 \%$ & $67,4 \%$ & $12,2 \%$ & $17,8 \%$ \\
\hline \multirow{2}{*}{ Activity orientated } & I & $43,8 \%$ & $44,1 \%$ & $50,6 \%$ & $50,2 \%$ & $5,6 \%$ & $5,7 \%$ \\
\cline { 2 - 9 } & II & $39,7 \%$ & $24,1 \%$ & $53,0 \%$ & $64,1 \%$ & $7,3 \%$ & $11,8 \%$ \\
\hline \multirow{2}{*}{ Reflexive } & I & $36,5 \%$ & $36,5 \%$ & $51,7 \%$ & $55,7 \%$ & $11,8 \%$ & $7,8 \%$ \\
\cline { 2 - 8 } & II & $33,2 \%$ & $22,1 \%$ & $53,7 \%$ & $60,1 \%$ & $13,1 \%$ & $17,8 \%$ \\
\hline
\end{tabular}

The dynamics of the professional culture level of specialists in the specialty 227 «Physical therapy, Ergotherapy» is clearly traced in the table and in the diagram (fig. 1).

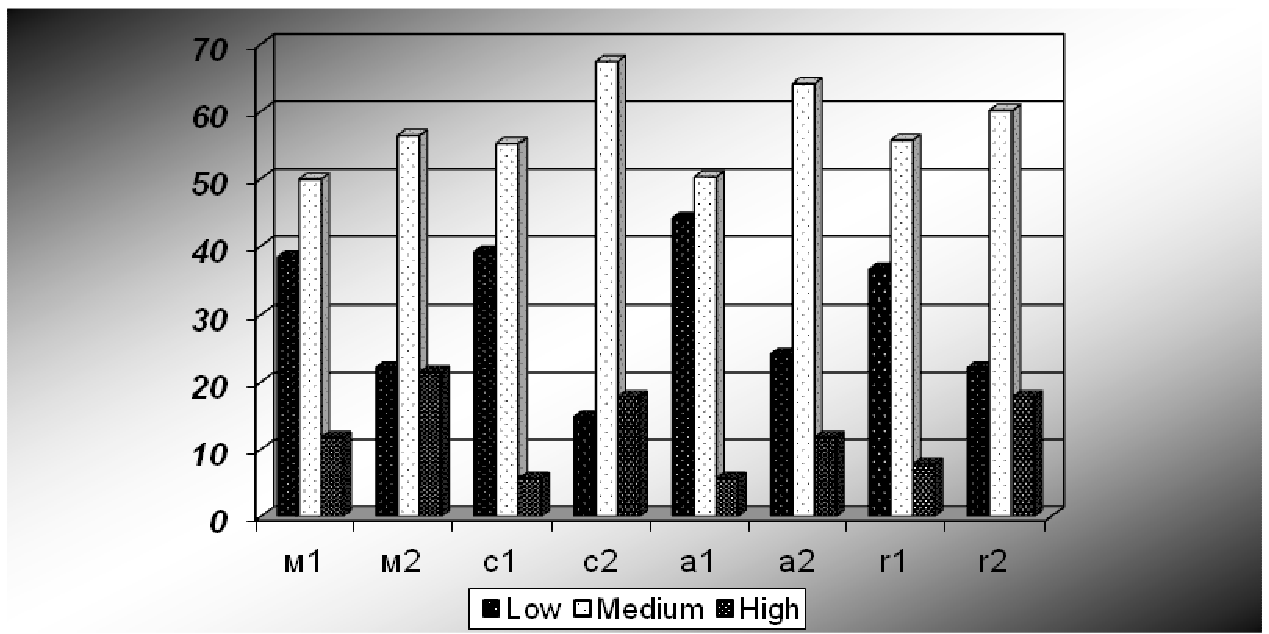

Fig. 1. Dynamics of components of professional culture formation in the experimental group, where $\mathrm{m} 1$ - the motivational component before the experiment; $\mathrm{m} 2$ - motivational component after the experiment; $\mathrm{c} 1$ - cognitive component before the experiment; $\mathrm{c} 2$ - cognitive component after the experiment; 
a1 - activity orientated component before the experiment; a 2 - activity orientated component after the experiment;

r1 - reflexive component before the experiment; $r 2$ - reflexive component after the experiment.

It was found that in the experimental group the level of motivational component of students increased by $16.2 \%$, cognitive - by $24.3 \%$, activity - by $19.9 \%$, reflexive - by $24.3 \%$. In the control group, the changes are insignificant.

\section{Discussion}

The number of scientific papers related to the training of future physical therapists and ergotherapists is increasing recently. Let's compare their research with ours.

Yu. Kopochynska (Kopochynska, 2020b), Hammond R., Cross V., Moore A. (Hammond et al., 2016) studied the professional identity of future specialists in physical therapy, ergotherapy. In the structure of professional identity, the author identified such components as motivational, cognitive, operationaltechnological, personal, behavioral. Yu. Kopochynska also defined the criteria for the professional identity formation: motivational-valuable, cognitive, activity orientated, communicative, emotional-empathic (Kopochynska, 2020b; Kopochynska, 2020c; Kopochynska, 2020d) As a result of the introduction of an experimental system of professional identity formation of future specialists in physical therapy and ergotherapy, an increase in its level was observed in the applicants of the experimental group. Author's system by Yu. Kopochynska envisaged the introduction of innovative training technologies for future physical therapists and ergotherapists (modular training technologies, problem-oriented training, team-oriented training, situational training, project-oriented training, information and communication technologies) and non-formal education for future physical therapy and ergotherapy specialists (Kopochynska, 2020a; Kopochynska et al., 2020).

However, the technologies of contextual learning in the preparation of students in specialty 227 «Physical Therapy, Ergotherapy» were not the subject of research by scientists, so the proposed article begins to study this problem.

The professional identity of future physical therapists and ergotherapists is closely linked to their professional culture. O. Nalyvayko (a future family doctor) (Nalyvayko, 2016), Yu. Kolisnyk-Humeniuk (a future medical specialist) (Kolisnyk-Humenyuk, 2012) dedicated their scientific works to the professional culture of future specialists. However, it should be noted that the professional culture of future physical therapists was considered only in the publication by T. Fedirchik and A. Brazhanyuk (Fedirchik et al., 2020), which was theoretically substantiated the essence of it.

Our research not only theoretically justifies the essence of the professional culture of future physical therapists and ergotherapists, but it also experimentally tests the effectiveness of the method of its formation in the process of professional training of students in a higher education institution.

\section{Conclusions}

As a result of theoretical analysis of scientific literature it is established that the professional culture of future specialists in physical therapy and ergotherapy will be an integrative characteristic of their preparation for future professional activity, which is based on highly developed personal qualities, knowledge and values, general and professional competencies, projecting a general culture of personality within the scope of the profession and contribute to the qualitative performance of professional tasks.

The content of professional training of higher education students for the speciality 227 «Physical Therapy, Ergotherapy» provides disciplines aimed at forming the professional culture of the future specialist (including philosophy, history of Ukrainian culture, pedagogy, general and clinical psychology, basics of sociology and law, correctional pedagogy, inclusive education, ethics of business communication, social psychology, psychology of a healthy lifestyle, psychology of additive behavior, etc.).

Training of future specialists in physical therapy and ergotherapy should be organized taking into account the contextual approach, which involves training based on real situations of professional activity. Business games, solving situational problems, case methods, projects implementation, modeling of patient rehabilitation situations and many others are effective.

Conflicts of interest. The authors declare no conflict of interest.

\section{References}

Batarshev, A. V., Alekseeva, I. Yu., Mayorova, E. V. (2007). Diagnostics of professionally important qualities. St. Petersburg: Peter [in Russian].

Bazylchuk, O. V. (2019). Theoretical and methodological basis of professional training of future specialists in physical therapy, ergotherapy to work with athletes' health recreation: thesis for scientific degree of doctor of pedagogic sciences: 13.00.04. Khmelnytskyi: Khmelnytskyi National University [in Ukrainian].

Bazylchuk, O., Putrov, S., Bazylchuk, V., Sushchenko, L., Galina, I. (2018). Problems of implementing innovational educational technologies in the process of vocational training of future specialists in physical 
therapy in higher educational establishments in Ukraine, Journal of Physical Education and Sport, 18 (2), 606-613.

Bespalova, O. O. (2019). Formation of readiness of future physical therapy ang ergotherapy bachelors for the aplication of physical and recreational technologies in professional activities: thesis for the degree $\mathrm{PhD}$ : 13.00.04. Sumy: Sumy State Pedagogical University named after A. S. Makarenko [in Ukrainian].

Bespalova, O. (2019). Teacher of academic department for a person's health, rehabilitation, physical therapy and ergotherapy. Scientific herald of the Institute of vocational education and training of NAES of Ukraine. Professional Pedagogy, 1(18), 62-66. https://doi.org/10.32835/2223-5752.2019.18.62-66

Bielikova, N. O. (2010a). Basic aspects of professional training of future specialists in physical rehabilitation in Poland. Pedagogy, psychology and medical and biological problems of physical education and sports, 3, 710 [in Ukrainian].

Bielikova, N. (2010b). Structure and content of training of specialists in physical rehabilitation in some European countries. Proceedings of Uman State Pedagogical University. P. Ticini, 1, 19-26 [in Ukrainian].

Boyko, V. V., Klitsenko, O. A. (2002). Assessment of personality empathy. St. Petersburg [in Russian].

Diachenko-Bohun, M., Hrytsai, N., Grynova, M., Grygus I., Zukow W. (2019). The readiness formation of future biology teachers for healthcare-safety technologies realization in professional activity. Education and Information Technologies. 24(1), 679-691. https://doi.org/10.1007/s10639-018-9799-y

Educational program «Physical therapy, ergoherapy» of the first (bachelor's) level of higher education in the specialty 227 «Physical therapy, ergoherapy» in the field of knowledge 22 «Health Care». URL: https://www.rshu.edu.ua/images/osvitni_programi/osv_prog bak 227 fiz terapi ergoter_2020.pdf

Fedirchik, T. D., Brazhanyuk, A. O. (2020). Professional culture of future physical therapists and occupational therapists: essence-component analysis. Innovative pedagogy, 22, V. 4, 169-171. https://doi.org/10.32843/2663- 6085/2020/22-4.34 [in Ukrainian].

Gusak, V. M. (2010). Ways of formation of professional culture of future social workers in the conditions of university. Scientific works of the Petro Mohyla Black Sea State University of the Kyiv-Mohyla Academy complex: Pedagogy, 136, 123, 69-73 [in Ukrainian].

Hammond, R., Cross, V., Moore, A. (2016). The construction of professional identity by physiotherapists: A qualitative study, Physiotherapy, 102, 71-77, doi:10.1016/j.physio.2015.04.002

Hrytsai, N. B. (2019). Context-oriented training of future biology teachers in pedagogical institutions of higher education. Professionalism of the teacher in the context of educational innovations / edited by Dr. hab. in Pedagogics, Professor Lyudmyla Havrilova. Hameln, Germany: InterGING, 2019. 167-180.

Hrytsai, N. B. Features of professional culture formation of future specialists in physical therapy, ergotherapy (2020). Revistă ştiințifică progresivă (Progressive scientific journal). Chişinău: «Fabrica Disa», Republica Moldova, Vol. 3, 1 (3). 9-12.

Kolisnyk-Humenyuk, Yu. I. (2012). Formation of professional and ethical culture of future specialists in the process of humanitarian training at medical colleges: dissertation for submitting a scientific degree of candidate of pedagogical sciences on specialty 13.00.04. Vinnytsya: Vinnytsya State Pedagogical University named after Mykhailo Kotsyubynskyy [in Ukrainian].

Kopochynska, Yu. (2020a). Introduction of innovative pedagogical technologies in the process of professional training of future specialists physical therapy, ergotherapy professionals. Vector of modern pedagogical and psychological science in Ukraine and EU countries: Collective monograph. Riga: Baltija Publishing, 337352.

Kopochynska, Yu. (2020b). Formation of professional reflection of future specialists in physical therapy, ergotherapy Engineering and Educational Technologies, 8 (1), 48-58. https://doi.org/10.30929/23079770.2020.08.01.04

Kopochynska, Yu. (2020c). Formation of the activity-operational component of the professional identity of future specialists in physical therapy, ergotherapy. Actual issues of humanitarian sciences, 29, V. 2, 226-230. https://doi.org/10.24919/2308-4863.2/29.209478

Kopochynska, Yu. V. (2020d). Research of the structure of professional identity of future professionals in physical therapy, ergotherapy. Innovative pedagogy, 22, V. 2, 71-75. https://doi.org/10.32843/26636085/2020/22-2.16

Kopochynska, Yu. V. (2020e). Retrospective analysis of professional identity of future professionals in physical therapy, ergotherapy. Innovative pedagogy, 21, V.2, 120-123. https://doi.org/10.32843/26636085/2019.21.2-27

Kopochynska, Yu., Kuksa, N., Glynyana, O., Karpenko, Y., Liakhova, I. (2020). The introduction of modular training technologies in the process of training future specialists in physical therapy, ergotherapy as a condition for the apprenticeship of professional identity. Journal of Physical Education and Sport, 20, 494500.

Korpi, H., Piirainen, A., Peltokallio, L. (2017). Practical work in physiotherapy students' professional development, Reflective Practice, 821-836, doi: 10.1080/14623943.2017.1361920

Liannoi, Yu. O. (2017). Theoretical and Methodological Foundations of Professional Training of Future Masters in Physical Rehabilitation at Higher Educational Establishments: thesis for the degree of Doctor in 
Pedagogical Sciences, speciality 13.00.04. Kyiv: National Pedagogical Dragomanov University [in Ukrainian].

Mordvinova, I. V., Olkhovyk, A. V. (2018). Preparation of Students in Specialty «Physical Therapy» and «Ergotherapy» in Countries of Europe. Pedagogical sciences: theory, history, innovative technologies, $1(75), 152-161$.

Nalyvayko, O. B. (2016). Formation of professional culture of future family doctors in the process of contextual training: thesis for the degree PhD: 13.00.04. Vinnytsia: Vinnytsia State Pedagogical University named after Mykhailo Kotsyubynsky [in Ukrainian].

Psychological tests (2002). under. ed. ed. A. A. Karelina: In 2 volumes. Moscow: VLADOS, V.1 [in Russian].

Resolution of the Cabinet of Ministers of Ukraine of February 1, 2017 № 53 «On Amendments to the Resolution of the Cabinet of Ministers of Ukraine of April 29, 2015 № 266». URL: https://zakon.rada.gov.ua/laws/show/53-2017-\%D0\%BF [in Ukrainian].

Soltyk, O., Pavlyuk, Ye., Vynogradskyi, B., Pavlyuk, O., Chopyk, T., \& Antoniuk, O. (2017). Improvement of professional competence of future specialists in physical education and sports during the process of vocational training. Journal of Physical Education and Sport, 17 (3), 964-969. doi:10.7752/jpes.2017.s3148

Standard of higher education of the first (bachelor's) level, field of knowledge 22 «Health care», specialty 227 «Physical therapy, ergotherapy» (2018). URL: https://mon.gov.ua/storage/app/media/vishchaosvita/zatverdzeni\%20standarty/12/21/227-fizichna-terapiya-ergoterapiya-bakalavr.pdf [in Ukrainian].

Sushchenko, L. P. (2015). The Development of Skills of Future Specialists in Physical Therapy in the Process of Vocational Training, Physical education, sports and health culture in modern society, 3(31), $52-55$ (in Ukranian).

Sushchenko, O. M. (2019). Development of professional competence of future masters in physical therapy, occupational therapy in the process of production practice: thesis for the degree PhD. 13.00.04. Sumy: Sumy State Pedagogical University named after A. S. Makarenko [in Ukrainian].

Verbitsky, A. A. (2004). Competence-based approach and the theory of contextual learning. Moscow: IC PKPS [in Russian].

Yakuba, E. A. (1996). Sociology: a textbook for students. Kharkov: Publishing house: «Constant» [in Russian].

Ziebart, C., MacDermid, J. C. (2019). Reflective Practice in Physical Therapy: A Scoping Review, Physical Therapy, 99:8, 1056-1068. 